\title{
Effect of Integrate Use of Phosphorus, PSB and Vermicompost on Acid and Alkaline Phosphatase Activity and Yield of Green Gram (Vigna radiata L.)
}

\author{
G. Bhavya*, K. Chandra Shaker, G. Jayasree and M. Malla Reddy \\ Department of Soil Science and Agricultural Chemistry, Agricultural College, Poalsa, Jagtial, \\ Professor Jayashankar Telangana State Agricultural University, Telangana State, India \\ *Corresponding author
}

\section{A B S T R A C T}

Field experiment was conducted during kharif, 2016 on sandy loam soil to study the effect of phosphorus levels, biofertilizers (PSB) and organic manures (vermicompost) on acid

Keywords

Phosphorus, PSB, Acid and alkaline phosphatase

\section{Article Info}

Accepted:

12 December 2017

Available Online:

10 January 2018 and alkaline phosphatase enzyme activity and yield of green gram. The experiment was laid out in randomized block design with three replications having 12 treatment combinations viz. 3 levels of phosphorus (0, 75 and $100 \%$ RDP) and its integration with PSB $\left(2 \mathrm{~kg} \mathrm{ha}^{-1}\right)$ and vermicompost $\left(5 \mathrm{t} \mathrm{ha}^{-1}\right)$. Application of inorganic $\mathrm{P}$ alone decreased phosphotase enzyme activity from 0 to $100 \%$ RDP level. Application of $100 \%$ RDP ha ${ }^{-1}$ resulted in a significantly lower acid and alkaline phosphatase activity both at flowering and at harvest of green gram. Application of vermicompost along with PSB seed inoculation $\left(\mathrm{T}_{4}\right)$ recorded significantly highest and activity of acid and alkaline phosphatase was 151.33 and $277.33 \mu \mathrm{g}$ p-nitrophenol $\mathrm{g}^{-1}$ soil $\mathrm{h}^{-1}$ and the lowest activity of 88.00 and $232.00 \mu \mathrm{g}$ p-nitrophenol $\mathrm{g}^{-1}$ soil $\mathrm{h}^{-1}$ of acid and alkaline phosphatase activity respectively were registered under $100 \%$ RDP treatment $\left(\mathrm{T}_{9}\right)$ in rhizosphere soil at flowering. Combined application of $100 \%$ RDP along with PSB and vermicompost registered significantly highest grain and haulm yield in green gram.

\section{Introduction}

India is the largest producer of pulses in the world. In India, green gram represents $18 \%$ (34.4 lakh hectares) of total pulse area and $11.48 \%$ (514 lakh tonnes) of pulse production (CMIE, 2014-15). Green gram is the third important pulse crop cultivated through India for its multipurpose use as vegetable, pulse, fodder and green manure crop, as it occupies good position due to its high seed protein content and ability to store the soil fertility through symbiotic nitrogen fixation. Despite occupying a greater position both in respect of area and production, the productivity of green gram is low compared to world average. One reason for this could be the imbalanced nutrient management. Farmers are not applying fertilizers and also cultivating green gram in marginal low fertile soils under rainfed conditions.

Phosphorus plays pivotal structural and regulatory role at the nexus of photosynthesis, root development, energy conservation and transformation, carbon metabolism, enzyme 
activation and nucleic acid synthesis (Vance $e t$ al., 2003). The very high phosphatic fertilizer prices also demand the need for recycling and exploitation of fixed phosphorus to improve crop production. The availability of phosphorus to the crop can be augmented by providing appropriate strains of microbes which are known to solubilise the fixed phosphorus and mobilize the deeply placed phosphorus to root zone by their activity. Besides increasing the availability of native $\mathrm{P}$ in the soil also help in enhancing the use efficiency of applied phosphorus (Thenua and Sharma, 2011). Organic matter additions were found to mobilize the fixed phosphates in the soil thus increasing the available $\mathrm{P}$ to crops (Venkateswarlu, 2000). Keeping all these points in view a field experiment was conducted to study the effect of phosphorus, PSB, vermicompost on growth and yield of green gram.

\section{Materials and Methods}

A field experiment was conducted during Kharif, 2016 at College Farm, Agricultural College, Professor Jayashankar Telangana State Agricultural University, Polasa, Jagtial, Telangana State. The soil of the experimental field was sandy loam in texture and slightly alkaline in reaction $(\mathrm{pH}$ 7.84) having an organic carbon content of $0.364 \%, 157.5 \mathrm{~kg}$ available nitrogen ha ${ }^{-1}, 18.6 \mathrm{~kg}$ available $\mathrm{P}_{2} \mathrm{O}_{5}$ $\mathrm{ha}^{-1}, 164.8 \mathrm{~kg}$ available $\mathrm{K}_{2} \mathrm{O} \mathrm{ha}^{-1}$, and $19.4 \mathrm{~kg}$ available sulphur ha ${ }^{-1}$.

The experiment was laid out in randomized block design with three levels of phosphorus $(0,75$ and $100 \%$ RDP $)$ and its integration with biofertilizers (PSB) and organic manures (vermicompost), all together 12 treatments replicated thrice. The various treatments were control ( $\mathrm{T}_{1^{-}}$without any $\mathrm{P}$ application), seed inoculation of PSB $\left(\mathrm{T}_{2}\right)$, application of vermicompost @ $5 \mathrm{t} \mathrm{ha}^{-1}\left(\mathrm{~T}_{3}\right)$, PSB + vermicompost $\left(\mathrm{T}_{4}\right), 75 \% \operatorname{RDP}\left(\mathrm{T}_{5}\right), 75 \%$
RDPP + PSB $\left(\mathrm{T}_{6}\right), 75 \% \mathrm{RDP}+$ vermicompost $\left(\mathrm{T}_{7}\right), 75 \% \mathrm{RDP}+\mathrm{PSB}+$ vermicompost $\left(\mathrm{T}_{8}\right)$, $100 \%$ RDP $\left(\mathrm{T}_{9}\right), 100 \%$ RDP + PSB $\left(\mathrm{T}_{10}\right)$, $100 \%$ RDP + vermicompost $\left(\mathrm{T}_{11}\right)$ and $100 \%$ RDP + PSB + vermicompost $\left(T_{12}\right)$. The plots are uniformly basal dressed with $20 \mathrm{~kg}$ urea and $20 \mathrm{~kg} \mathrm{~K}_{2} \mathrm{O} \mathrm{ha}{ }^{-1}$ and phosphorus applied as per the treatments. PSB and vermicompost applied as per the treatments. Rhizobium seed treatment was given to all the treatments. The green gram variety used LGG 460 sown with a spacing of $30 \mathrm{~cm} \mathrm{X} 10 \mathrm{~cm}$. The soil samples from individual treatmental plot were collected at flowering and after harvest and assayed for acid and alkaline phosphatase activities in the rhizosphere soil as described by Tabatabai and Bermner (1969) and Eivazi and Tabatabai (1977).

\section{Results and Discussion}

\section{Acid phosphatase activity}

Acid phopsphatase activity in the rhizosphere soil significantly decreased with increasing the level of phosphorus application. Lowest phosphatase activity of 88.00 and $42.33 \mu \mathrm{g} \mathrm{p}$ nitrophenol $\mathrm{g}^{-1}$ soil $\mathrm{h}^{-1}$ was recorded in $100 \%$ RDP treatment $\left(\mathrm{T}_{9}\right)$ in rhizosphere soil at flowering and harvest, respectively which was significantly lower than the activity of 89.67 and $45.33 \mu \mathrm{g}$ p-nitrophenol $\mathrm{g}^{-1}$ soil $\mathrm{h}^{-1}$ in the control at flowering and harvest, respectively.

Significantly higher acid phosphatase activity of 151.33 and $66.33 \mu \mathrm{g}$ p-nitrophenol $\mathrm{g}^{-1}$ soil $\mathrm{h}^{-1}$ was recorded with combined application of PSB and vermicompost $\left(\mathrm{T}_{4}\right)$ at flowering and harvest, respectively. It was evident from earlier research that under conditions of $\mathrm{P}$ deficiency the acid phophatase secreted from roots was increased and the plant roots applied with organic $\mathrm{P}$ or without $\mathrm{P}$ was significantly enhanced compared with those grown in inorganic P (Nakas et al., 1987; Li et al., 1997; Hays et al., 1999) (Table 1). 
Table.1 Haulm and seed yield $\left(\mathrm{kg} \mathrm{ha}^{-1}\right)$, acid and alkaline phosphatase activity $\left(\mu \mathrm{g} \mathrm{g}^{-1} \mathrm{soil} \mathrm{h}^{-1}\right)$ of green gram as influenced by graded levels of $\mathrm{P}$ in integration with vermicompost and PSB

\begin{tabular}{|c|c|c|c|c|c|c|}
\hline \multirow[t]{2}{*}{ Treatments } & \multicolumn{2}{|c|}{ Yield $\left(\mathrm{kg} \mathrm{ha}^{-1}\right)$} & \multicolumn{2}{|c|}{$\begin{array}{l}\text { Acid phosphatase activity } \\
\left(\mu g \mathrm{~g}^{-1} \text { soil }^{-1}\right)\end{array}$} & \multicolumn{2}{|c|}{$\begin{array}{l}\text { Alkaline phosphatase } \\
\text { activity }\left(\mu \mathrm{g} \mathrm{g}^{-1} \text { soil } \mathrm{h}^{-1}\right)\end{array}$} \\
\hline & Haulm & Grain & At flowering & At harvest & At flowering & At harvest \\
\hline$T_{1}$ & 993.33 & 703.33 & 89.67 & 45.33 & 242.67 & 119.33 \\
\hline$T_{2}$ & 1037.33 & 724.33 & 143.67 & 65.00 & 271.67 & 144.00 \\
\hline$\overline{T_{3}}$ & 1066.66 & 749.67 & 139.67 & 63.33 & 271.33 & 142.33 \\
\hline$T_{4}$ & 1157.33 & 771.33 & 151.33 & 66.33 & 277.33 & 157.33 \\
\hline $\mathbf{T}_{5}$ & 1259.33 & 831.00 & 88.33 & 42.67 & 238.00 & 119.17 \\
\hline $\mathrm{T}_{6}$ & 1275.00 & 853.00 & 108.87 & 55.67 & 268.33 & 139.33 \\
\hline $\mathbf{T}_{7}$ & 1379.66 & 868.67 & 104.00 & 52.17 & 265.33 & 135.00 \\
\hline$T_{8}$ & 1411.66 & 928.67 & 131.67 & 61.67 & 271.60 & 141.33 \\
\hline $\mathrm{T}_{9}$ & 1456.66 & 956.67 & 88.00 & 42.33 & 232.00 & 118.60 \\
\hline$T_{10}$ & 1518.33 & 985.00 & 92.67 & 50.67 & 252.00 & 128.00 \\
\hline$T_{11}$ & 1566.00 & 996.00 & 91.67 & 46.00 & 249.00 & 123.00 \\
\hline $\mathbf{T}_{12}$ & 1625.66 & 1033.33 & 93.33 & 51.00 & 257.33 & 129.33 \\
\hline CD & 87.87 & 56.36 & 10.77 & 10.66 & 12.83 & 11.47 \\
\hline SE(D) & 42.37 & 27.17 & 5.19 & 5.14 & 6.18 & 5.53 \\
\hline
\end{tabular}

\section{Alkaline phosphatase activity}

Alkaline phosphatase activity in the rhizosphere was higher as compared to acid phosphatase activity. Application of vermicompost along with PSB inoculation $\left(\mathrm{T}_{4}\right)$ recorded significantly highest alkaline phosphatase activity of 277.33 and $157.28 \mu \mathrm{g}$ p-nitrophenol $\mathrm{g}^{-1}$ soil $\mathrm{h}^{-1}$ at flowering and harvest, respectively. Lowest phosphatase activity of 232.00 and $118.60 \mu \mathrm{g}$ pnitrophenol $\mathrm{g}^{-1}$ soil $\mathrm{h}^{-1}$ was recorded in $100 \%$ RDP treatment $\left(\mathrm{T}_{9}\right)$ in rhizosphere soil at flowering and harvest, respectively.

At flowering stage $100 \% \mathrm{RDP}^{-1}+\mathrm{PSB}$, $100 \%$ RDP $\mathrm{ha}^{-1}+$ vermicompost and $100 \%$ RDP

$\mathrm{ha}^{-1}+\mathrm{PSB}+$ vermicompost application significantly increased the alkaline phophatase activity over alone application of $100 \%$ RDP $\mathrm{ha}^{-1}$. This could be due to the reason that the activity of PSB was greater at lower levels of P than higher levels and microbial population increased due to inoculation with PSB (Sarawgi et al., 1999).

\section{Yield of green gram}

The grain yield and haulm yield significantly influenced by different phosphorus management practices. The seed yield was the highest when vermicompost and PSB were combinedly applied with inorganic $\mathrm{P}$ at $100 \% \mathrm{RDP}\left(\mathrm{T}_{12}\right)$, the yield being $1033.33 \mathrm{~kg} \mathrm{ha}^{-1}$ and it was found to be on par with $\mathrm{T}_{11}\left(996 \mathrm{~kg} \mathrm{ha}^{-1}\right)$ and $\mathrm{T}_{10}$ $\left(985.00 \mathrm{~kg} \mathrm{ha}{ }^{-1}\right)$ treatments. Integrated application of inorganic $\mathrm{P}$ along with vermicompost and PSB significantly increased the seed yield by $46.92 \%\left(\mathrm{~T}_{12}\right.$ on $\left.\mathrm{T}_{1}\right), 11.75 \%$ $\left(\mathrm{T}_{8}\right.$ on $\left.\mathrm{T}_{5}\right)$ and $8 \%\left(\mathrm{~T}_{12}\right.$ on $\left.\mathrm{T}_{9}\right)$ at $\mathrm{P}_{0} . \mathrm{P}_{75}$ and $\mathrm{P}_{100}$ levels, respectively over inorganic $\mathrm{P}$ application at their respective level. Application of $75 \%$ RDP alone $\left(\mathrm{T}_{5}\right)$ significantly increased the seed yield to $831.00 \mathrm{~kg} \mathrm{ha}^{-1}$ over $703.33 \mathrm{~kg}$ $\mathrm{ha}^{-1}$ in control $\left(\mathrm{T}_{1}\right)$. The increased seed yield with $P$ application might be due to increased $P$ availability and uptake resulted profuse nodulation leading to greater symbiotic nitrogen fixation which in turn has positive effect on photosynthesis, then on yield (Rani et al., 2016 and Kumar et al., 2014). 
Haulm yield was increased from a value of $993.33 \mathrm{~kg} \mathrm{ha}^{-1}$ in the control $\left(\mathrm{T}_{1}\right)$ to $1625.66 \mathrm{~kg}$ $\mathrm{ha}^{-1}$ in the treatment $\left(\mathrm{T}_{12}\right)$ which was receiving $100 \%$ RDP along with vermicomost and PSB and it was on par with $\mathrm{T}_{11}$ treatments. However, addition of $75 \%$ RDP alone $\left(\mathrm{T}_{5}\right)$ significantly increased the haulm yield to $1259.33 \mathrm{~kg} \mathrm{ha}^{-1}$ over control $\left(\mathrm{T}_{1}\right)$. Rathour et al., (2014) reported that phosphorus involves in cell division, increases various metabolic processes and cell enlargement, application of phosphate solubilising bacteria releases growth promoting substances which improves the haulm yield.

\section{References}

CMIE 2014-15. Centre for Monitoring Indian Economy, Apple Heritage, Mumbai.

Eivazi F and Tabatabai M A 1977. Phosphotases in soils. Soil Biology and Biochemistry. 9: 167-172.

Hays, J.E., Richardson, A.E and Simpson, R.J. 1999. Phytase and acid phosphatase activities and extracts sfrom roots of pasture grass and legume seedlings. Australian Journal of Plant Physiology. 26: 801-809.

Kumar, S., Tomar, S and Tomar, T.S. 2014. Integrated phosphorus management in black gram (Vigna mungo) in western Uttar Pradesh during summer season. Annals of Agricultural Research. 35(3): 290-297.

Li, M.G., Osaki, M., Rao, I.M and Tandano, T. 1997. Secretion of phytase from the roots of several species under phosphorus conditions. Plant and Soil. 195: 161-169.

Nakas, J.P., Gould, W.D and Klein, D.A. 1987. Orgin and expression of phosphatase activity in semi-arid grassland soil. Soil
Biology and Biochemistry. 19: 13-18.

Rani, M., Prakash, V and Khan, K. 2016. Response of mungbean [Vigna radiata (L.) Wilczek] to phosphorus and sulphur and PSB during summer season. Agricultural Science Digest. 36(2): 146148.

Rathour, D., Sadhu, A.C and Suryawanshi, P.K., 2014. Integrated phosphorus management in summer green gram (Vigna radiata L.). Advance Research Journal of Crop Improvement. 5(1): 5759.

Sarawagi, S.K., Tiwari, P.K and Tripathi, R.S. 1999. Uptake and balance sheet of nitrogen and Phosphorus in gram (Cicer arietinum) as influenced by phosphorus, biofertilizer and micronutrients under rainfed condition. Indian Journal of Agronomy. 44(4): 768-772.

Tabatabai M A and Bremner J M. 1969. Use of P-nitrophenyl phosphate for assay of soil phosphatase activity. Soil Biology and Biochemistry. 1: 301-307.

Thenua, O.V.S and Sharma, R.K. 2011. Effect of phosphorus, sulphur and phosphate solubilizing bacteria on productivity and nutrient uptake of chickpea. Annals of Agricultural Research. 32(3\&4): 116119.

Vance, C.P., Uhde Stone, C and Allan, D.L., 2003. Phosphorus and Use: Critical adaptations by plants securing a nonrenewable resource. New Phytologist. 157, 423-457.

Venkateswarlu, B., 2000. Land configurations and fertilizer management for sustainable groundnut production. Ph.D. thesis. Gujarat Agricultural University, Sardar Krishinagar, Gujarat.

\section{How to cite this article:}

Bhavya, G., K. Chandra Shaker, G. Jayasree and Malla Reddy, M. 2018. Effect of Integrate Use of Phosphorus, PSB and Vermicompost on Acid and Alkaline Phosphatase Activity and Yield of Green Gram (Vigna radiata L.). Int.J.Curr.Microbiol.App.Sci. 7(01): 1465-1468. doi: https://doi.org/10.20546/ijcmas.2018.701.178 